\title{
Migrant Care's Role in Advocating the Educational Needs of Migrant Workers' Children
}

\author{
Irma Indrayani Arief ${ }^{1}$ \\ DOI: $10.35445 /$ alishlah.v13i3.1440
}

\begin{tabular}{l}
\hline Article Info \\
\hline Keywords: \\
Migrant Care; \\
Children of Migrant \\
Workers; \\
Community Learning \\
Center; \\
Government
\end{tabular}

Kata kunci: Migrant Care; Anak Buruh Migran; Community Learning Center; Pemerintah

\begin{abstract}
Education is a fundamental human need and a right of every citizen. Indonesia is one of the origin countries for many migrant workers. There is a complex problem with migrant workers, one of which is the education of migrant workers' children. Numerous civil society organizations, including Migrant Care, advocate for the rights of migrant workers. The purpose of this study is to examine Migrant Care's role in advocating for the educational needs of children of migrant workers and to analyze the factors that support and obstruct Migrant Care's ability to perform its function. The research method is qualitative-descriptive, with data being gathered via interviews and literature review. Data analysis begins with collecting data from various sources, which is then described and validated. This study makes use of role theory, interest groups, and systems theory. The findings of this research are Migrant Care's efforts to obtain official documents for migrant workers and to lobby the government for Community Learning Centers (CLC).
\end{abstract}

\begin{abstract}
Abstrak
Pendidikan merupakan kebutuhan dasar manusia dan hak setiap warga negara. Indonesia merupakan salah satu negara asal dengan banyak pekerja migran. Ada permasalahan yang kompleks dari pekerja migran, salah satunya adalah masalah pendidikan anak pekerja migran. Banyak kelompok masyarakat sipil yang fokus memperjuangkan hak-hak buruh migran, salah satunya Migrant Care. Penelitian ini bertujuan untuk melihat peran Migrant Care dalam mengadvokasi kebutuhan pendidikan anak pekerja migran dan menganalisis faktor pendukung dan penghambat Migrant Care dalam menjalankan fungsinya. Metode penelitian yang digunakan adalah kualitatif-deskriptif dengan pengumpulan data melalui wawancara dan studi kepustakaan. Analisis data dengan mengumpulkan informasi dari sumber-sumber yang kemudian dideskripsikan dan validasi data. Penelitian ini menggunakan teori peran dan konsep kelompok kepentingan dan teori sistem. Temuan penelitian ini adalah upaya Migrant Care kepada pemerintah untuk Community Learning Center (CLC) dan pengadaan dokumen resmi bagi pekerja migran.
\end{abstract}

\section{INTRODUCTION}

Indonesia is one of the second most significant countries of origin for migrant workers in Southeast Asia. In the last decade, the issue of migrant workers, especially those who work abroad, has received special attention from the Indonesian government (Silvey \& Parreñas, 2020). The issue of migrant workers is very strategic and related to a large number of workers. There is also the complexity

\footnotetext{
1 Universitas Nasional, Jakarta, Indonesia

Email: irma.indrayani@civitas.unas.ac.id
} 
of the problems of migrant workers (Moyce \& Schenker, 2018). One of them is the problem of access to education for the children of migrant workers abroad (Regmi et al., 2019).

The author observes that economic reasons are the main driving factor for migrant workers to migrate abroad, given the limited job opportunities in their own country and unemployment and poverty (Akanle et al., 2021). Migration has become a powerful instrument for migrant workers to fulfil their needs and improve their welfare (Wahab, 2020).A large number of Indonesian workers is accompanied by an increase in the number of children of migrant workers abroad who do not have documents and have difficulties in obtaining their education rights. This fundamental right becomes difficult for the state to fulfil because several countries, such as Malaysia, prohibit the existence of CLC (Community Learning Center) in their country (Reyes-Veras et al., 2021).

The Indonesian state's efforts to ensure the right to education for the children of migrant workers continue to face obstacles, particularly in presenting CLC in several foreign countries. Nonetheless, the Indonesian government makes efforts through its representatives to ensure that its citizens have access to education. In Article 28 (1) of the Convention on the Rights of the Child, which was approved by the United Nations (UN) General Assembly on November 20, 1989, it is stated that participating countries recognize the child's right to education and commit to implementing this right gradually and on an equal opportunity basis. In Indonesia, the state's obligation to educate its citizens is governed by the values enshrined in Pancasila and the 1945 Constitution's Preamble (Dewantara et al., 2019).

Meanwhile, Article 9 paragraph (1) of Law No. 35 of 2014 amending Law No. 23 of 2002 concerning Child Protection states that every child has the right to education and instruction in the context of personal development and intelligence level according to interests and talents (Herrero \& Lorenzo, 2020). Article 31 paragraph (1) of the 1945 Constitution's Chapter XIII on Education and Culture states that every citizen has the right to education. Then, paragraph (3) states that the government seeks and organizes a national education system that fosters faith and piety, as well as a noble character, in the nation's intellectual life (Hadi, 2019).

Based on the above, the writer examines the educational services for children of migrant workers. Based on the data obtained, the number of migrant workers residing abroad annually reaches hundreds of thousands, with almost a third of these workers living Overseas.

\begin{tabular}{|c|c|}
\hline Year & Number of Migrant Workers Overseas \\
\hline 2011 & 586.802 \\
\hline 2012 & 494.609 \\
\hline 2013 & 512.168 \\
\hline 2014 & 429.872 \\
\hline 2015 & 275.736 \\
\hline 2016 & 234.451 \\
\hline 2017 & 262.899 \\
\hline 2018 & 283.640 \\
\hline 2019 & 276.553 \\
\hline 2020 & 113.173 \\
\hline
\end{tabular}

This number includes informal migrant workers. Meanwhile, from data obtained based on interviews with the Indonesian Consulate General in Malaysia, there are at least 2,500 children of undocumented migrant workers who are still of school age and cannot get an education. The children are scattered in the working area of the Indonesian Consulate General in Johor Bahru. This can then show that around 1-3\% of the children of Migrant workers have not received proper education (Cavaille \& Marshall, 2019).

The children of migrant workers can access education in private schools in their country. However, accessing education in these private schools costs a lot of money for migrant workers (Bonjour \& Duyvendak, 2018). In addition, there are several problems, such as children's documents. This is 
because some of the children of migrant workers were born and raised abroad, so they do not have complete documents. Some are illegal because they do not have birth certificates or official residence documents. This illegal status prevents many children of migrant workers from accessing education in foreign schools (Webber, 2019).

Another issue is the immigration status of the parents of migrant workers' children. Nonprofessional workers are prohibited from marrying fellow workers in certain foreign countries, according to immigration regulations (Son \& Shin, 2020). Meanwhile, there are numerous instances of migrant workers marrying residents solely for religious reasons. In other instances, migrant workers bring their children from Indonesia, and children born abroad are abandoned by their foreign fathers (Ullah \& Alkaff, 2018). As a result of this case, the number of illegal migrant workers in Malaysia alone has risen to 53,000, with half of these children unable to attend school due to a lack of documentation. Parents of migrant workers' children are typically employed in the informal sector, on oil palm plantations, or as factory workers. For migrant workers with school-aged children, access to education is hampered by the distance between their place of residence and school, which is approximately two to six hours. Even though the distance between home and school is considerable, they are still required to return home daily. On the one hand, these migrant workers' children may be apprehended by police or other security forces and deported as a result of their illegal status (Piipponen \& Virkkunen, 2020). As a non-profit organization dedicated to advocating for the rights of migrant workers and their families, it is in Migrant Care's interest to advocate for the government, which is responsible for ensuring that the children of migrant workers have access to education (Gammage \& Stevanovic, 2019). Given that many children of Indonesian migrant workers were raised outside the country, it is critical to instil a sense of the country's values. As a result, the authors note that the children of migrant workers face barriers to education abroad.

Through the explanation above, the researcher wants to research to know Migrant Care's efforts in advocating for the educational needs of children of Indonesian migrant workers and explaining the obstacles encountered by the government in providing educational services for children of Indonesian migrant workers. The theory is a tool that combines and assembles concepts into an explanation that shows how these concepts are related. An idea is a form of a statement that answers the question "why," which means that theorizing is an attempt to give meaning to the phenomena that occur. Meanwhile, the government system can be interpreted as a structure consisting of legislative, executive, and judicial functions that are interconnected, working together, and influencing one another. Thus, the system of government is the way state institutions work with each other (Bodin, 2017). According to Jimly Asshidiqie, the government system is defined as a system of relations between state institutions. Meanwhile, according to Sri Soemantri, the system of government is the relationship between the legislative and executive institutions. Ismail Suny believes that the government system is a particular system that explains the connection between the highest state equipment in a country (Ibrahim et al., 2021).

\section{METHODS}

This study uses a descriptive analytical qualitative research type, where the research focuses on describing and analyzing the efforts of Migrant Care in advocating for the educational needs of migrant workers' children. In addition, this study also analyzes the driving and inhibiting factors for Migrant Care in carrying out its roles. The data in this study were obtained from primary data sources and secondary data, with data collection techniques used through observation, in-depth interviews, and literature/document studies. In addition, researchers seek complementary information related to the roles of Migrant Care through media such as electronic media and other media such as books, transcripts, newspapers, other documents. Data analysis techniques researchers carry out data collection, data reduction, data presentation, and drawing conclusions and verification. 


\section{FINDINGS AND DISCUSSION \\ Establishment of CLC (Community Learning Center) in Various Countries}

The Community Learning Center, commonly known as CLC, is an official place for learning activities located in the territory of Malaysia. CLC has many benefits for children of migrant workers in Malaysia because CLC waives fees for students whose parents work in the fields, although it is still paid for students whose parents work non-farm. Usually, to pay for local teachers and rent buildings for these schools, CLCs spread across Malaysia are affiliated with Sekolah Indonesia as the parent-school, which supports CLC SD, and SMP spread across Malaysia in the form of learning support and financing. Students who complete their studies at CLC will get the same formal diploma as students who study in traditional schools, namely a certificate issued by the Ministry of Education and can continue studying to the next level. The certification is obtained through the Pursuit Equality Education Program Packages $\mathrm{A}, \mathrm{B}$, and $\mathrm{C}$. The program is organized by the Consulate General of the Republic of Indonesia.

Unfortunately, the CLC program is limited to Malaysia, while other migrant destination countries still have many limitations. Therefore, Migrant Care has a role in encouraging the government to establish CLCs in countries that have a large number of migrant workers, such as Saudi Arabia. Through the establishment of CLC, children of migrant workers in other countries can have access to education that is on par with other formal schools. This is certainly in line with Migrant Care's program advocating for various policies that favour migrant workers and ensure their implementation. In addition, Migrant Care also utilizes information technology for service effectiveness and campaigns to garner public support to realize safe migration (Gottlieb et al., 2012; Armenta \& Sarabia, 2020). Then Migrant Care also has a program in education to create a critical awareness of Indonesian Migrant Workers and their family members about their rights as workers and citizens. In this case, the right to education is essential for the children of migrant workers who are abroad.

The form of advocacy that can be carried out by Migrant Care can be carried out through providing input to the government, both at the centre or various Indonesian embassies abroad, to establish CLC, which aims to provide education to the children of migrant workers. This can also be done by establishing cooperation with the Consulate General in Malaysia and the Ministry of Education to imitate the formation of CLC in Malaysia. Implementation of the establishment of CLC following the mandate of the Convention on the Rights of the Child and able to provide education for the children of migrant workers (Dhungana, 2020; Alam \& Houston, 2020). The education provided is "education for all" without discrimination to children of migrant workers who are usually excluded because they are considered illegal. CLC in Malaysia itself managed to have 14,213 students in 2019 so that the influence of CLC on access to education for children of migrant workers is quite incredible. Therefore, Migrant Care needs to advocate for the government to fulfil the rights of children of migrant workers in obtaining their education.

\section{Procurement of Resident Documents}

The problem with children of migrant workers that causes many of them not to get an education is the issue of official documents or residence documents. Many do not have official documents because they entered Malaysia through illegal or illegal routes. Many of them also lack an understanding of the terms and what to bring when entering another country. Migrant Care can advocate for the Indonesian government to help issue official documents to deal with the education problems of children of migrant workers. The official documents that can be advocated by Migrant Care to the Indonesian government are as follows (Rosa, 2019; Murphy \& Rodis, 2020; Purch et al., 2020):

a) Passport Issuance

Migrant Care may be able to persuade the government to implement online registration for Indonesian migrant workers seeking passports while abroad. This online passport issuance registration program aims to make life easier for migrant workers working abroad, particularly those who work in remote locations. Indirectly, this program is also intended for children of migrant workers who wish to apply for a passport, which is a requirement for admission to 
school. Although many migrant workers can now apply for passports online, many are unable to do so due to a lack of time or understanding of information technology (D'cruz \& Banerjee, 2020). Additionally, children of migrant workers are not always able to complete this online registration. Registration of a passport, particularly for illegal migrants abroad, informs the government that the migrant worker is illegal, and it is feared that this will make it more difficult for illegal migrant workers.

As a result, Migrant Care must advocate for the government's escorting of these migrants. By registering passports, the government can demonstrate that it is attempting to protect its citizens abroad by ensuring their citizens have an identity or official documents and by ensuring that their citizens receive an education while they are outside the country.

b) Issuance of Birth Certificate

The issue of birth registration or citizenship status has a very close relationship with the issue of access to education, especially for TKI children who do not have complete documents. Many children of Indonesian citizens abroad do not have birth certificates and have difficulty accessing education. Therefore, Migrant Care needs to advocate for the Indonesian government to issue birth certificates for children of migrant workers born abroad or do not have one.

In addition to access to education, birth registration is an obligation for all Indonesian citizens residing abroad. Based on Law no. 23 of 2006, concerning Population Administration, every Indonesian citizen living abroad is required to report to the local government and the Representative of the Republic of Indonesia (RI), which includes their place of residence regarding the presence, relocation, change of address, status of residence permit, as well as other important events ( such as birth, marriage, divorce, or death). For every Indonesian citizen who is abroad and stays more than five days, it is highly recommended to report his whereabouts to the local Indonesian Representative (Zendedel et al., 2016; Rumbold et al., 2020). This will make it easier for the Indonesian citizen concerned if he gets a problem abroad because the Indonesian Representative has his data.

Many migrant workers marry and have children abroad but do not yet have birth documents in the country. They generally cannot afford to travel freely due to cost issues and the risks involved in travelling with undocumented children. Therefore, the government needs to assist these migrant workers through various birth certificates in concentration areas where migrant workers live.

This is undoubtedly a challenge for the Indonesian government in providing protection and services for migrant workers. Moreover, the spread of migrant workers in various countries can make it challenging to give the best service for migrant workers abroad (Collins \& Bayliss, 2020). The issuance of this Birth Certificate will also indirectly help the children of migrant workers who have not yet received an education due to problems with their official documents.

c) Implementation of Marriage Itsbat Session

Furthermore, Migrant Care can advocate for the Indonesian government to hold an Itsbat Marriage session or marriage ratification for migrant workers married to foreign nationals or married to fellow migrant workers from Indonesia but have only just married religiously and have not been legalized by the state.

This plan is carried out so that migrant workers from Indonesia have official documents and indirectly make it easier to arrange birth certificates and passports for their children's school registration requirements (Setyoningsih, 2013; Nasution, 2017). Suppose you look back on the issue of visas. It is difficult for children of migrant workers from Indonesia to apply for passports because many of their parents do not have passports and do not have official marriage documents. Besides aiming to provide legal protection, this activity is also expected to increase the awareness of migrant workers on the importance of citizenship documents, which are not only required when dealing with local agencies but can also make it easier to manage their child's 
education registration so that this can then provide a sense of security in the event of a legal circumstance.

\section{Factors that can support and inhibit migrant care in implementing advocacy to the government}

Referring to the five success factors of social movements proposed by Locher, it can be analyzed the supporting factors for Migrant Care in carrying out its role to advocate for the educational needs of children of migrant workers in the form of effective leadership capable of being a supporting element for Migrant Care in carrying out its roles, by seeing aspects of leadership as a vital instrument in the organizational managerial process. Migrant Care's positive image is also one of the supporting factors. It can establish credibility and bargaining position for Migrant Care to carry out its roles and interact with other actors in state administration interactions (Rahayu \& Abheseka, 2020). The accepted tactics, strategies, and goals are other supporting factors. Seeing Migrant Care can formulate steps and strategies relevant to the existing situation to be considered capable of playing a solution. Then, support from human and financial resources is also one of the supporting factors. On the other hand, the political aspect can also support Migrant Care in carrying out its roles.

Various internal and external aspects can form situations that can become a supporting factor for Migrant Care in carrying out its roles to advocate for the government in meeting the educational needs of children of migrant workers. Meanwhile, in analyzing the inhibiting factors for Migrant Care in carrying out its roles, this study looks at factors from external and internal aspects of the organization (Collins \& Bayliss, 2020). Externally, there are at least four inhibiting situations, namely: The migrant worker placement industry is increasing and strengthening; The government's perspective has not been in favour of migrant workers; Foreign policy and diplomacy for the protection of migrant workers that have not been realized; and Corruption in the service of migrant workers.

Meanwhile, internally, the dynamics of the organization in various aspects trigger stagnation in the journey of Migrant Care. The lack of solid analysis results, the absence of institutional competition, and a system of criticism/self-criticism cause stagnation for Migrant Care in carrying out its roles.

\section{CONCLUSION}

Through the results of the research above, it can be found that Migrant Care can advocate for the government to be able to provide educational needs to children of migrant workers through various programs such as the establishment of CLC to provide education to children of migrant workers or through the documentation for migrant workers and their children so that they have access to formal education and can escape legal problems in the future. Then this research can also help identify the supporting factors and inhibiting factors for the role of Migrant Care, indicating that there are situations that occur, both internally and externally to the organization, which then support and hinder the functions carried out Migrant Care.

\section{REFERENCES}

Akanle, O., Fayehun, O. A., Adejare, G. S., \& Orobome, O. A. (2021). International migration, kinship networks and social capital in Southwestern Nigeria. Journal of Borderlands Studies, 36(2), 319332.

Alam, A., \& Houston, D. (2020). Rethinking care as alternate infrastructure. Cities, 100, 102662.

Armenta, A., \& Sarabia, H. (2020). Receptionists, doctors, and social workers: Examining undocumented immigrant women's perceptions of health services. Social Science \& Medicine, $246,112788$.

Bodin, Ö. (2017). Collaborative environmental governance: achieving collective action in socialecological systems. Science, 357(6352).

Bonjour, S., \& Duyvendak, J. W. (2018). The "migrant with poor prospects": racialized intersections of class and culture in Dutch civic integration debates. Ethnic and Racial Studies, 41(5), 882-900. 
Cavaille, C., \& Marshall, J. (2019). Education and anti-immigration attitudes: Evidence from compulsory schooling reforms across Western Europe. American Political Science Review, 113(1), 254-263.

Collins, F. L., \& Bayliss, T. (2020). The good migrant: Everyday nationalism and temporary migration management on New Zealand dairy farms. Political Geography, 80, 102193.

Collins, F. L., \& Bayliss, T. (2020). The good migrant: Everyday nationalism and temporary migration management on New Zealand dairy farms. Political Geography, 80, 102193.

Daraba, D., Cahaya, A., Guntur, M., Aslinda, A., \& Akib, H. (2018). Strategy of governance in transportation policy implementation: Case study of bus rapid transit (BRT) program in Makassar City. Academy of Strategic Management Journal, 17(3).

D'cruz, M., \& Banerjee, D. (2020). 'An invisible human rights crisis': The marginalization of older adults during the COVID-19 pandemic-An advocacy review. Psychiatry research, 113369.

Dewantara, J. A., Suhendar, I. F., Rosyid, R., \& Atmaja, T. S. (2019). Pancasila as Ideology and Characteristics Civic Education in Indonesia. International Journal for Educational and Vocational Studies, 1(5), 400-405.

Dhungana, N. (2020). Human dignity and cross-border migrants in the era of the COVID-19 pandemic. World Development, 136, 105174.

Eisenstadt, S. N. (2020). The challenge of multiple modernities. In New horizons in sociological theory and research (pp. 99-126). Routledge.

Gammage, S., \& Stevanovic, N. (2019). Gender, migration and care deficits: what role for the sustainable development goals?. Journal of Ethnic and Migration Studies, 45(14), 2600-2620.

Gottlieb, N., Filc, D., \& Davidovitch, N. (2012). Medical humanitarianism, human rights and political advocacy: the case of the Israeli open clinic. Social Science \& Medicine, 74(6), 839-845.

Hadi, N. (2019). Concept of educational values for Tauhid nation education system perspective. Indonesian Journal of Islamic Education Studies (IJIES), 2(1), 1-16.

Herrero, J. F., \& Lorenzo, G. (2020). An immersive virtual reality educational intervention on people with autism spectrum disorders (ASD) for the development of communication skills and problem solving. Education and Information Technologies, 25(3), 1689-1722.

Ibrahim, Y., Ismail, R. A., Ogungbenro, A., Pankratz, T., Banat, F., \& Arafat, H. A. (2021). The sociopolitical factors impacting the adoption and proliferation of desalination: A critical review. Desalination, 498, 114798.

Kronenberg, J., Andersson, E., Barton, D., Borgström, S., Langemeyer, J., Björklund, T., ... \& Wolff, M. (2021). The thorny path toward greening: unintended consequences, trade-offs, and constraints in green and blue infrastructure planning, implementation, and management. Ecology and Society, 26(2).

Moyce, S. C., \& Schenker, M. (2018). Migrant workers and their occupational health and safety. Annual review of public health, 39, 351-365.

Murphy, E. M., \& Rodis, J. L. (2020). The pharmacist's role in advocating for the health care of immigrants in detention centers. Journal of the American Pharmacists Association, 60(4), e1-e6.

Nasution, R. (2017). Model Advokasi LSM JKPS Cahaya Terhadap Buruh Migran Asal Kabupaten Ponorogo. Jurnal Masalah-Masalah Hukum, 46(1), 30-48.

Niemi, K. (2021). 'The best guess for the future?'Teachers' adaptation to open and flexible learning environments in Finland. Education Inquiry, 12(3), 282-300.

Ortega, P., Diamond, L., Alemán, M. A., Fatás-Cabeza, J., Magaña, D., Pazo, V., ... \& Ríos, E. (2020). Medical Spanish standardization in US medical schools: consensus statement from a multidisciplinary expert panel. Academic Medicine, 95(1), 22-31.

Palma Carvajal, J. F. (2021). Advocacy NGOs and the neoliberal manufacture of the street voice. Journal of Education Policy, 1-21.

Piipponen, M., \& Virkkunen, J. (2020). The Remigration of Afghan Immigrants from Russia. Nationalities Papers, 48(4), 644-66o.

Pizzarossa, L. B., Perehudoff, K., \& Forte, J. C. (2018). How the Uruguayan judiciary shapes access to high-priced medicines: A critique through the right to health lens. Health and human rights, 20(1), 93 .

Pursch, B., Tate, A., Legido-Quigley, H., \& Howard, N. (2020). Health for all? A qualitative study of NGO support to migrants affected by structural violence in northern France. Social Science \& Medicine, 248, 112838. 
Rahayu, M., \& Abheseka, N. M. R. (2020). Advokasi Perempuan Desa dalam Memperkuat Perlindungan bagi Pekerja Migran: Bermigrasi Aman Berkat Perdes dan Perda Perlindungan TKI= Village Women's Advocacy for Strengthening Migrant Worker Protection: Safe Migration under Village and District Regulations.

Regmi, P. R., Van Teijlingen, E., Mahato, P., Aryal, N., Jadhav, N., Simkhada, P., ... \& Gaidhane, A. (2019). The health of Nepali migrants in India: A qualitative study of lifestyles and risks. International journal of environmental research and public health, 16(19), 3655.

Requena, F. (2019). The Catholic Church and consolidation of democratic civil society in Spain. Journal of Civil Society, 15(3), 249-266.

Reyes-Veras, P. F., Renukappa, S., \& Suresh, S. (2021). Challenges faced by the adoption of big data in the Dominican Republic construction industry: an empirical study. Journal of Information Technology in Construction (ITCON), 26, 812-831.

Rosa, B. V. (2019). Resident bid preference, affiliation, and procurement competition: Evidence from new mexico. The Journal of Industrial Economics, 67(2), 161-208.

Rumbold, A. R., Yelland, J., Stuart-Butler, D., Forbes, M., Due, C., Boyle, F. M., \& Middleton, P. (2020). Addressing stillbirth inequities in Australia: Steps towards a better future. Women and Birth, $33(6), 520-525$.

Schewel, K. (2020). Understanding immobility: Moving beyond the mobility bias in migration studies. International Migration Review, 54(2), 328-355.

Setyoningsih, E. (2013). Peran LSM Migrant CARE dalam Membantu Bermasalah di Arab Saudi Tahun 2009 dan 2010. Journal of Politic and Government Studies, 2(1), 261-270.

Silvey, R., \& Parreñas, R. (2020). Precarity chains: Cycles of domestic worker migration from Southeast Asia to the Middle East. Journal of Ethnic and Migration Studies, 46(16), 3457-3471.

Son, I., \& Shin, H. (2020). Decentered identity negotiation and dilemmas among Korean-Chinese immigrants in South Korea. Asian and Pacific Migration Journal, 29(4), 469-491.

Wahab, A. (2020). The outbreak of Covid-19 in Malaysia: pushing migrant workers at the margin. Social Sciences \& Humanities Open, 2(1), 100073.

Webber, F. (2019). On the creation of the UK's 'hostile environment'. Race \& Class, 6o(4), 76-87.

Zendedel, R., Schouten, B. C., van Weert, J. C., \& van den Putte, B. (2016). Informal interpreting in general practice: Comparing the perspectives of general practitioners, migrant patients and family interpreters. Patient education and counseling, 99(6), 981-987. 